\title{
DURUM WHEAT CULTIVARS' ANTIOXIDANT AND NITRATE ASSIMILATORY ENZYME RESPONSE TO BIPOLARIS SOROKINIANA INFECTION
}

\author{
KOMAL MALI ${ }^{1}$, KIRAN KAMALAKAR MIRAJKAR ${ }^{2}$, \\ SUMA BIRADAR ${ }^{3}$ \& RENUKA SUDARSHAN PATIL ${ }^{4}$ \\ ${ }^{1,2,4}$ Department of Biochemistry, College of Agriculture Sciences, University of \\ Agricultural Sciences, Dharwad, Karnataka, India \\ ${ }^{3}$ Main Agricultural Research Station, University of Agricultural Sciences, Dharwad, Karnataka, India
}

The biochemical responses of the foliar antioxidant and nitrate assimilatory enzymes to Bipolaris sorokiniana infection were studied in resistant (NIDW295 and PDW314) and susceptible (Bijaga Yellow and A-3-901) durum wheat cultivars. 30 day old durum wheat cultivars were inoculated with spore suspension $\left(10^{6} \mathrm{ml}^{1}\right)$ of Bipolaris sorokiniana and the uninfected plants served as control. The activities of reactive oxygen species (ROS) scavenging enzymes namely superoxide dismutase (SOD), catalase (CAT) and glutathione reductase (GR) were strongly induced, while those of nitrate reductase and nitrite reductase were suppressed in inoculated leaves (48 hrs post inoculation) compared to healthy ones. The SOD, CAT and GR recorded maximum increase of 344\%, $74 \%$ and $157 \%$ respectively in the resistant cultivars, suggesting their induction for detoxifying ROS synthesized during Bipolaris sorokiniana infection. The relatively lower activities of antioxidant enzymes in the susceptible cultivars make them more prone to oxidative injury than the resistant cultivars. The minimum decline in enzyme activities of nitrite and nitrate reductase in resistant cultivars $(29.2 \%$ and $25.7 \%$ respectively) showed adequate nitrogen regulation, while the susceptible cultivars lacked the ability to maintain the nitrogen metabolism under infection. Thus, our study revealed significant differences in antioxidant enzyme and nitrate assimilatory activities between the Durum wheat cultivars, which may serve as a useful tool in selection of resistant cultivars.

KEYWORDS: Bipolaris Sorokiniana, NIDW295, Bijaga Yellow, Durum Wheat Cultivars, Superoxide Dismutase \& Nitrate Reductase
\end{abstract}

Received: Jun 05, 2017; Accepted: Jun 20, 2017; Published: Jul 19, 2017; Paper Id.: IJASRAUG201741

\section{INTRODUCTION}

Spot blotch caused by Bipolaris sorokiniana (Sacc.) is one of the major foliar diseases that limit the cultivation of wheat in warmer and humid regions of the world (Chowdhury et al. 2013). The pathogen causes deterioration in seed quality, reduces yield, germination, seedling emergence and rooting intensity in the subsequent crops (Joshi, 1986). The grain yield reduction due to spot blotch varies from 15.5 to19.6\% in general and 20 to $80 \%$ depending upon weather conditions, cultivars and pathogen population (Duveiller and Gilchrist, 1994). Emerging newer strains with increased virulence pose a major threat to wheat production and productivity at the global level (Kumar et al. 2016). Although a number of attempts have been made for efficient management of B.sorokiniana, by using disease resistant varieties of wheat, efficient crop rotation techniques and biological controlling agents, spot blotch remains a disease of serious concern under warmer areas (Acharya et al. 2011). Therefore there is a need for understanding the mechanism of resistance and the selection of genotypes with durable levels of resistance to spot 
blotch.

The plants defense response to infection by fungi is often manifested as the hypersensitive reaction (HR) characterized by production of reactive oxygen species (ROS), lignin deposition and cellwall crosslinking (Bradley et al. 1992; Brisson, et al. 1994), synthesis of pathogen related proteins (Bowles, 1990) along with induction of rapid and localized death of host cells at the site of infection (Ingram, 1978; Tenhaken et al., 1995). The induction of ROSscavenging enzymes, such as superoxide dismutase (SOD) involved in the dismutation of the $\mathrm{O}^{2}$ - radical to molecular oxygen and hydrogen peroxide, catalase (CAT) and peroxidases (POXs), involved in the removal of $\mathrm{H}_{2} \mathrm{O}_{2}$, is the most common mechanism for detoxifying ROS synthesized during stress responses (Wojtaszek, 1997; Mittler, 2002). Glutathione reductase (GR) activity maintains an enhanced level of reduced glutathione which is involved in maintaining antioxidant capacity. High antioxidant capacity of plants plays a crucial role in inducing resistance to fungal colonization (Waller et al. 2005).

Nitrate reductase (NR) provides a good approximation of the nitrogen level of plants and is associated with growth and plant yield (Srivastava, 1980). Nitrate assimilation is affected by various environmental factors including the host pathogen interaction. The information about the changes in the nitrate assimilatory system of durum wheat cultivars during Bipolaris sorokiniana infection is limited. Therefore, this study aimed to determine alterations in the levels of antioxidant enzymes activities of SOD, CAT and GR and nitrate assimilatory enzymes in four durum wheat cultivars with different levels of resistance to spot blotch.

\section{MATERIALS AND METHODS}

\section{Plant Material and Experimental Design}

Four cultivars of Durum wheat (Triticum turgidum spp.Durum) NIDW295, PDW314 (resistant) and BijagaYellow, A-9-301 (susceptible) were selected to study the biochemical response of antioxidant enzymes and nitrate assimilatory enzymes to Bipolaris sorokiniana infection. Two different plots, one for inoculated and another for uninoculated (control) were used for evaluating each cultivar under field conditions and followed a randomized complete block design with three replications (Mali et al. 2017) Spore suspension of B. sorokiniana $\left(10^{6} \mathrm{ml}^{-1}\right)$, isolated from fungal cultures, was sprayed on to the leaves of durum wheat cultivars (30 days after sowing) until run off. Post inoculation (48 hrs) the activities of SOD; CAT, GR, NR and NiR were assessed in the diseased leaves in comparison with the uninoculated plants (healthy leaves) which served as control.

\section{Extraction of Enzyme and Determination of Protein Content}

Fresh leaf tissues after collection were processed immediately for enzyme extraction $\left(0^{\circ} \mathrm{C}-4^{\circ} \mathrm{C}\right)$ and assay. In order to measure the enzyme activities of SOD, CAT, GR, NR and NiR, $0.5 \mathrm{~g}$ of leaf tissue was taken per treatment, and ground into fine powder using liquid nitrogen and extracted in $2.0 \mathrm{~mL}$ of ice cold buffer. Extraction buffer for CAT and SOD contained $0.05 \mathrm{M}$ sodium phosphate buffer of $\mathrm{pH} 7.0$ and $\mathrm{pH} 7.8$, respectively. Grinding buffer for GR included $0.1 \mathrm{M}$ Tris $-\mathrm{HCl} \mathrm{pH} 7.8$ and $2 \mathrm{mM}$ dithiothreitol (DTT). Nitrate reductase (NR) and Nitrite reductase (NiR) enzyme extracts were prepared in $0.1 \mathrm{M}$ phosphate buffer, $\mathrm{pH} 7.5$, containing $10 \mathrm{mM}$ cysteine. The extraction buffers of all the enzymes contained $1 \mathrm{mM}$ ethylenediaminetetraacetic acid (EDTA) and $1.5 \% \mathrm{w} / \mathrm{v}$ insoluble polyvinyl polypyrrolidone was added during extraction. After centrifugation of homogenate at $14,000 \mathrm{rpm}$ for $20 \mathrm{~min}$ at $4{ }^{\circ} \mathrm{C}$, the supernatant was used immediately as source of enzyme for the assay. An aliquot of supernatant was stored at $-20^{\circ} \mathrm{C}$ for protein analysis which 
was determined by Bradford method using bovine serum albumin as standard (Bradford, 1976).

\section{Antioxidant Enzyme Activities}

Superoxide Dismutase

The activity of SOD, (EC 1.15.1.1) was assayed photochemically at $560 \mathrm{~nm}$ by the Beauchamp and Fridovich method. (Beauchamp and Fridovich, 1971). $3.0 \mathrm{~mL}$ of assay mixture contained $20 \mu \mathrm{L}$ of enzyme extract, L-methionine (10 $\mathrm{mM})$, p-nitrobluetetrazolium chloride (NBT) $(33 \mu \mathrm{M})$, EDTA $(0.66 \mu \mathrm{M})$ and riboflavin $(3.3 \mu \mathrm{M})$ in a $50 \mathrm{mM}$ potassium phosphate buffer, $\mathrm{pH}$ 7.8. The assay was initiated by adding riboflavin and took place in a glass tube illuminated by a $15 \mathrm{~W}$ fluorescent lamp at $25^{\circ} \mathrm{C}$ for 20 minutes. The increase in absorbance of the blue formazan produced by NBT photoreduction was measured at $560 \mathrm{~nm}$.A blank was maintained with all the constituents but in the dark. One unit of SOD is defined as the amount of enzyme required to inhibit $50 \%$ of the NBT photo-reduction per minute and specific activity is expressed as IU per mg protein.

\section{Catalase Assay}

CAT (EC 1.11.1.6) activity was spectrophotometrically determined by Beers and Sizers method (Beers and Sizer, 1952). The reaction mixture contained $2.98 \mathrm{~mL}$ of $16.65 \mathrm{mM}$ hydrogen peroxide in $50 \mathrm{mM}$ phosphate buffer, $\mathrm{pH} 7.0$ and 20 $\mu \mathrm{L}$ of enzyme extract was used to initiate the reaction. The decrease in absorbance at $240 \mathrm{~nm}$ was measured for 5 minutes using the substrate blank.. One unit of CAT is defined as the one $\mu$ mole of $\mathrm{H}_{2} \mathrm{O}_{2}$ decomposed per minute at $\mathrm{pH} 7.0$ at $25^{\circ} \mathrm{C}$ and specific activity was expressed as $\mu$ mole $\min ^{-1} \mathrm{mg}^{-1}$ protein.

\section{Glutathione Reductase Assay}

GR (EC 1.8.1.7) activity was determined spectrophotometrically by Mavis and Stellwagen method (Mavis and Stellwagen, 1968). The reaction mixture contained $100 \mu \mathrm{L}$ of $30 \mathrm{mM}$ oxidized glutathione, $1.5 \mathrm{~mL}$ of $100 \mathrm{mM}$ potassium phosphate buffer with $3.4 \mathrm{mM}$ EDTA, pH 7.6, $350 \mu \mathrm{L}$ of $0.8 \mathrm{mM}$ B-nicotinamide adenine dinucleotide phosphate, reduced form (NADPH) and $950 \mu \mathrm{L}$ of water. The decrease in absorbance at $340 \mathrm{~nm}$ on addition of $100 \mu \mathrm{L}$ of enzyme to reaction mixture was recorded for 5 minutes.. One GR unit is defined as the amount of enzyme that oxidises $1.0 \mu$ mole of NADPH per minute at $\mathrm{pH} 7.6$ at $25^{\circ} \mathrm{C}$ and specific activity is expressed as $\mu$ mole $\mathrm{min}^{-1} \mathrm{mg}^{-1}$ protein.

\section{Nitrate Reductase Assay}

NR (EC 1.7.1.1) activity was spectrophotometrically determined by the method of Hageman and Reed (Hageman and Reed, 1980). A known weight (140 mg) of fresh tissue was cut into pieces and suspended in screw cap vials containing $3.5 \mathrm{ml}$ of incubation mixture $(20 \mathrm{ml}$ of $0.1 \mathrm{M}$ phosphate buffer, $20 \mathrm{ml}$ of 5 per cent propanol and $10 \mathrm{ml}$ of 0.2 per cent KNO3). The vials were sealed and kept in dark condition at $30^{\circ} \mathrm{C}$ for $2 \mathrm{~h}$. Nitrite released into the medium was determined by treating $1 \mathrm{ml}$ aliquot with $1 \mathrm{ml}$ each of $1 \%$ sulphanyl amide and $0.02 \% \mathrm{~N}-1$ - napthyl ethylene diamine hydrochloride. After $20 \mathrm{~min}$, solution is diluted to $5 \mathrm{ml}$ with water and absorbance is measured at $540 \mathrm{~nm}$. Standard curve is prepared by using reagent grade concentrations of nitrite (KNO2) solution. The nitrate reductase activity is expressed as nmoles of nitrite formed per hour per gram fresh weight.

\section{Nitrite Reductase Assay}

NiR (EC 1.7.7.1) activity was determined spectrophotometrically by the method of Wray and Fido (Wray and Fido, 1990). The $0.8 \mathrm{ml}$ of reaction mixture contained $0.2 \mathrm{ml}$ of $0.1 \mathrm{M}$ phosphate buffer, $0.1 \mathrm{ml}$ of $5 \mathrm{mM}$ sodium nitrite, 0.1 
$\mathrm{ml}$ of $1.5 \mathrm{mM}$ methyl viologen, $50 \mu \mathrm{l}$ of enzyme and distilled water. The reaction was started by adding $0.2 \mathrm{ml}$ of the $2.5 \%$ sodium dithionite reagent and incubated for 10 minutes. The reaction was stopped by vigorously shaking the mixture until the dithionite was completely oxidized and the dye colour disappeared. For determination of nitrite consumed by enzyme $50 \mu \mathrm{l}$ aliquot of above mixture was made to $2.0 \mathrm{ml}$ using distilled water and $1.0 \mathrm{ml}$ of $1 \%$ sulphanilamide followed by 1 $\mathrm{ml}$ of $0.02 \%$ NNED was added and incubated for 15 minutes. Blank was also processed in the similar way except for $50 \mu 1$ of enzyme was added after the addition of sulphanilamide and NNED and read at $540 \mathrm{~nm}$. The nitrite consumed by the action of enzyme was estimated from the nitrite standard curve. NiR activity is expressed as $\mu \mathrm{mol}$ of nitrite consumed $/ \mathrm{min}$ and the specific activity as enzyme activity/mg protein.

\section{RESULTS}

\section{Superoxide Dismutase}

B.sorokiniana infection showed profound effect on SOD activity. Superoxide dismutase activity in the leaves of all the wheat cultivars differed significantly ( $\mathrm{p} \leq .01)$ in inoculated (48 hrs post inoculation) and uninoculated leaves (control) as given in Figure 1. The inoculated leaves of resistant NIDW295 and PDW314 cultivars recorded highest SOD activity $(8.63 \mathrm{U} / \mathrm{mg}$ proteins and $7.16 \mathrm{U} / \mathrm{mg}$ proteins respectively) as compared to control leaves $(1.94 \mathrm{U} / \mathrm{mg}$ proteins and $2.32 \mathrm{U} / \mathrm{mg}$ protein respectively). Inoculated leaves of susceptible A-9-301 and Bijaga Yellow cultivars showed least change in SOD activity $(1.72 \mathrm{U} / \mathrm{mg}$ proteins and $3.26 \mathrm{U} / \mathrm{mg}$ protein respectively) as compared to control leaves (1.2 $\mathrm{U} / \mathrm{mg}$ protein and $2.02 \mathrm{U} / \mathrm{mg}$ protein respectively). PDW314 and NIDW295 with 344\% and 208\% increase in SOD activity indicate strong induction of SOD as defense enzyme against B.sorokiniana infection whereas A-9-301 and Bijaga Yellow with $43.3 \%$ and $61.3 \%$ increase in SOD activity reflect their weak response and hence vulnerability to B.sorokiniana infection.

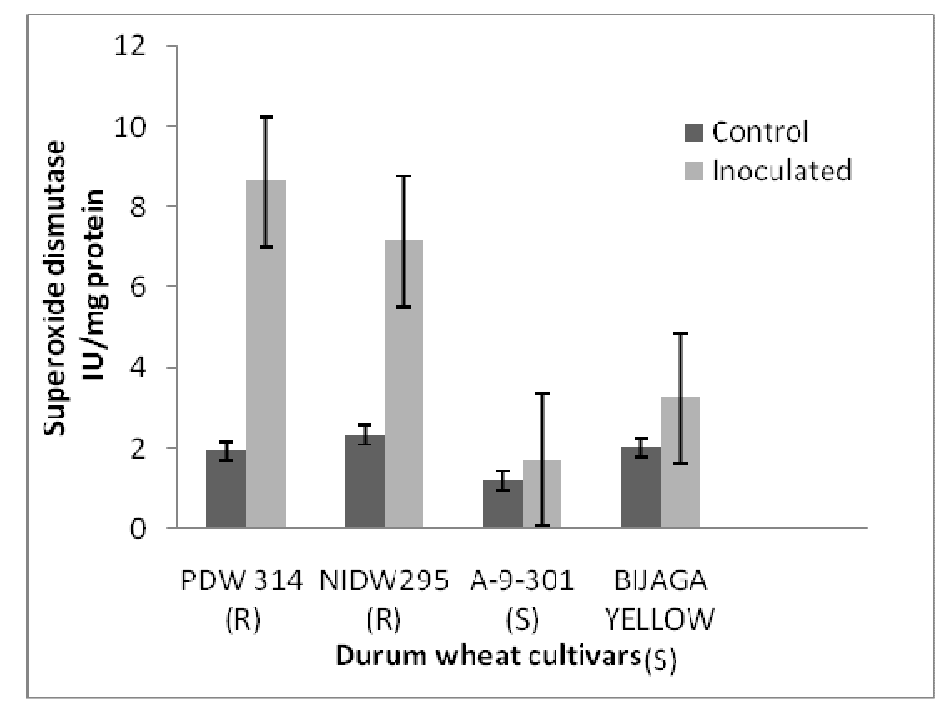

Figure 1: Specific Activity of Superoxide Dismutase in Leaves of Different Durum Wheat Cultivars in Response to Spot Blotch Infection $(\mathbf{R})=$ Resistant Cultivars, $(\mathbf{S})=$ Susceptible Cultivars

\section{Catalase}

The catalase activities were significantly $(\mathrm{p} \leq 0.01)$ greater in the inoculated leaves of all the durum wheat cultivars than those of the control leaves as represented in Figure 2. NIDW295 and PDW314 cultivars recorded significant alteration in catalase activity ( $703.16 \mathrm{U} / \mathrm{mg}$ protein and $623.33 \mathrm{U} / \mathrm{mg}$ protein respectively) as compared to control leaves ( 
$404 \mathrm{U} / \mathrm{mg}$ protein and $373 \mathrm{U} / \mathrm{mg}$ protein respectively). The response of catalase activity in inoculated leaves of susceptible A-9-301 and Bijaga Yellow cultivars was lower (383.66 U/mg protein and 423.33 U/mg protein respectively) as compared to resistant ones. Amongst all the cultivars the inoculated leaves of NIDW295 showed highest increase in catalase activity (74\%) whereas A-9-301 recorded least increase (21.8\%).

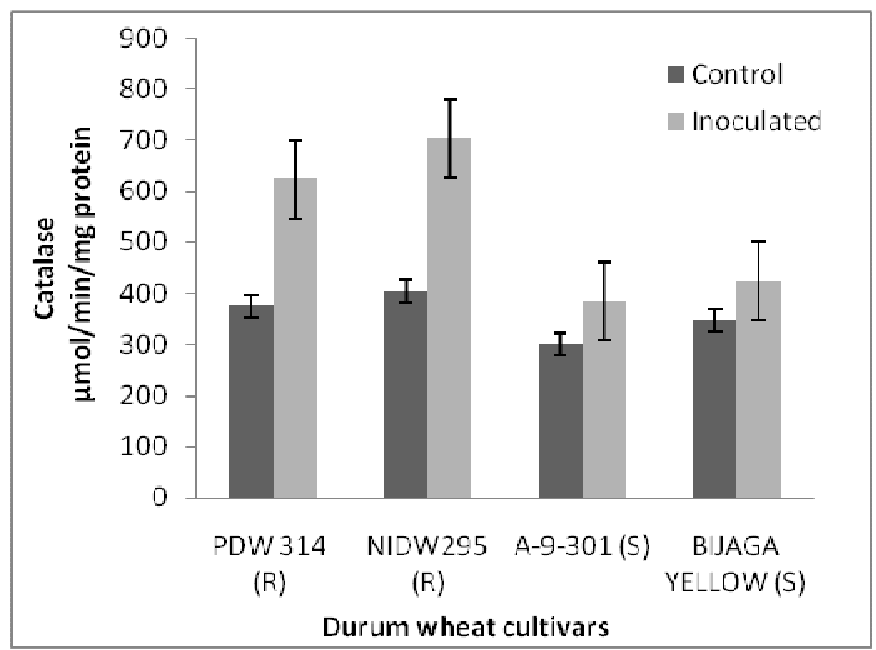

Figure 2: Specific Activity of Catalase in Leaves of Different Durum Wheat Cultivars in Response to Spot Blotch Infection $(R)=$ Resistant Cultivars, $(S)=$ Susceptible Cultivars

\section{Glutathione Reductase}

Glutathione reductase activity in the leaves of all the wheat cultivars differed significantly $(\mathrm{p} \leq 0.01)$ in control and $48 \mathrm{hr}$ after inoculation as given in the Figure 3. B.sorokiniana infection elicited variable response in GR activity amongst the cultivars. The inoculated leaves of resistant NIDW295 and PDW314 gave maximum response in glutathione reductase activity ( $3.423 \mathrm{U} / \mathrm{mg}$ protein and $3.233 \mathrm{U} / \mathrm{mg}$ protein respectively) as compared to control leaves (1.33U/mg protein and $1.34 \mathrm{U} / \mathrm{mg}$ protein respectively) while the Inoculated leaves of susceptible A-9-301 and Bijaga Yellow cultivars showed moderate response $(2.06 \mathrm{U} / \mathrm{mg}$ protein and $2.56 \mathrm{U} / \mathrm{mg}$ protein respectively) as compared to control leaves $(1.37 \mathrm{U} / \mathrm{mg}$ protein and $1.03 \mathrm{U} / \mathrm{mg}$ protein respectively). NIDW 295 recorded greatest induced activity and increase in Glutathione reductase activity $(157.1 \%)$ where as Bijaga Yellow showed least increase $(86.8 \%)$.

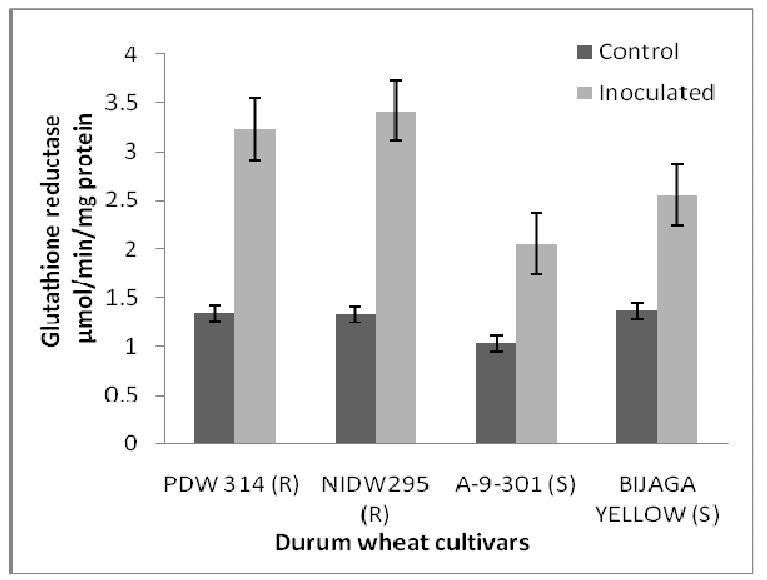

Figure 3: Specific Activity of Glutathione Reductase in Leaves of different Durum Wheat Cultivars in Response to Spot Blotch Infection. $(\mathbf{R})=$ Resistant Cultivars, $(\mathrm{S})=$ Susceptible Cultivars 


\section{Nitrate Reductase}

Nitrate reductase activity was significantly affected by B.sorokiniana infection. Levels of nitrate reductase in all the durum wheat cultivars were significantly lower in inoculated leaves $(55.58 \mathrm{nmoles} / \mathrm{hr} / \mathrm{g})$ as compared to control (94.47 nmoles/hr/g) as depicted in the Figure 4. Amongst all the cultivars, the nitrate reductase activity in the resistant NIDW295 and PDW314 was significantly higher (100.89 nmoles/hr/g and $87.06 \mathrm{nmoles} / \mathrm{hr} / \mathrm{g}$ respectively ) when compared to susceptible A-9-301 and genotypes Bijaga Yellow (62.28 nmoles /hr/g and $49.84 \mathrm{nmoles} / \mathrm{hr} / \mathrm{g}$ respectively). Inoculated leaves of susceptible A-9-301 and Bijaga Yellow cultivars showed highest decrease in nitrate reductase activity (39.23 $\mathrm{nmoles} / \mathrm{g} / \mathrm{hr}$ and $28.26 \mathrm{nmoles} / \mathrm{g} / \mathrm{hr}$ respectively) as compared to control leaves $(85.3 \mathrm{nmoles} / \mathrm{g} / \mathrm{hr}$ and $71.4 \mathrm{nmoles} / \mathrm{g} / \mathrm{hr}$ respectively). Resistant NIDW295 and PDW314 genotype recorded least decrease in nitrate reductase activity (82.66 nmoes/g/hr and 72.13 nmoles/g/hr respectively) as compared to control leaves (119.13 nmoles/h/hr and $102 \mathrm{nmoles} / \mathrm{g} / \mathrm{hr}$ respectively). Amongst all genotype inoculated leaves of Bijaga Yellow showed highest decrease in activity (60.4 \%) where PDW314 recorded least decrease $(29.28 \%)$

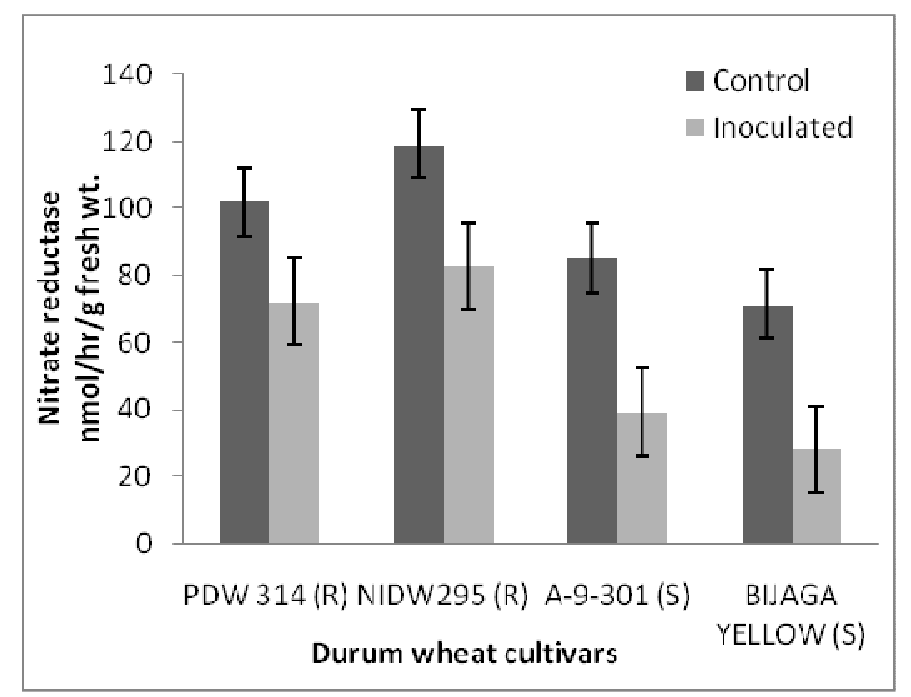

Figure 4: Activity of Nitrate Reductase in Leaves of Different Durum Wheat Cultivars in Response to Spot Blotch Infection $(R)=$ Resistant Cultivars, $(S)=$ Susceptible Cultivars

\section{Nitrite Reductase Activity}

In the present study, the NiR activity was decreased significantly $(\mathrm{p} \leq 0.01)$ in inoculated leaves as compared to control leaves in all the cultivars as represented in the Figure 5. B.sorokiniana infection caused higher decrease of NiR activity in susceptible A-9-301 and Bijaga Yellow cultivars than in the resistant NIDW295 and PDW314 ones. Inoculated leaves of susceptible A-9-301 and Bijaga Yellow showed highest decrease in nitrite reductase activity $(0.26 \mathrm{U} / \mathrm{mg}$ proteins and $0.29 \mathrm{U} / \mathrm{mg}$ protein respectively) as compared to control leaves $(0.61 \mathrm{U} / \mathrm{mg}$ and $0.57 \mathrm{U} / \mathrm{mg}$ respectively). Resistant NIDW295 and PDW314 cultivars recorded least decrease in nitrite reductase activity (0.57Umg protein and $0.49 \mathrm{U} / \mathrm{mg}$ protein respectively) as compared to control leaves $(0.73 \mathrm{U} / \mathrm{mg}$ protein and $0.66 \mathrm{U} / \mathrm{mg}$ protein respectively). Bijaga Yellow showed highest decrease in NiR activity (61.4\%) where as PDW314 recorded least decrease $(25.75 \%)$. 


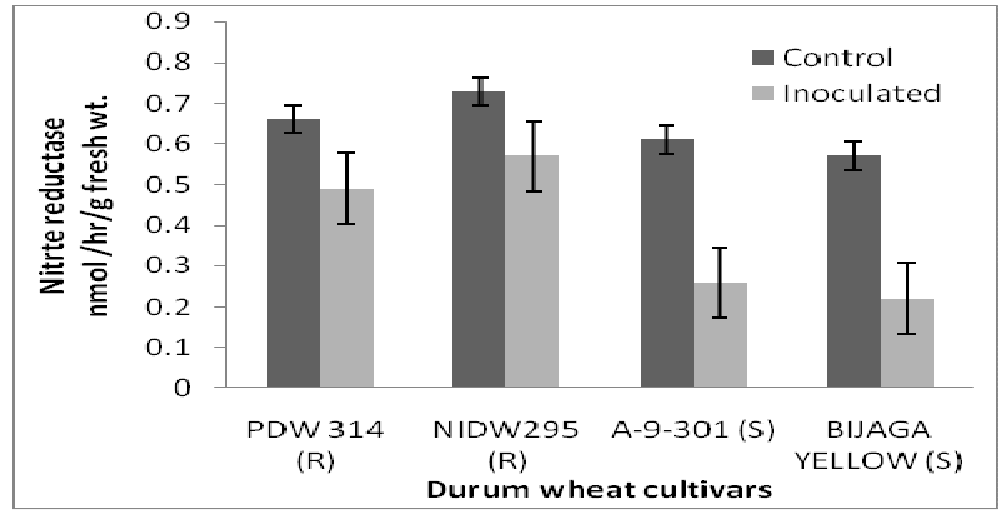

Figure.5: Activity of Nitrite Reductase in Leaves of Different Durum Wheat Cultivars in Response to Spot Blotch Infection $(R)=$ Resistant Cultivars, $(S)=$ Susceptible Cultivars

\section{DISCUSSIONS}

\section{Superoxide Dismutase}

In the present study, the SOD activities in the inoculated leaves were higher than those of control in all the cultivars, demonstrating SOD as an important protective mechanism against oxidative stress induced by B.sorokiniana infection. SOD activity revealed distinct differences in the durum wheat cultivars. The SOD activity increased by $3-4.44$ folds in the resistant NIDW295 and PDW314 cultivars whereas 1.4-1.6 folds increase was observed in susceptible A-9-301 and Bijaga Yellow cultivars These results are in accordance with the observations of Mahathma et al (2011) and Babitha etal (2002) where higher SOD activity was observed in resistant genotypes compared to susceptible in pearl millet under downy mild dew disease. Within a cell, the superoxide dismutase (SOD) constitutes the first line of defence against ROS (Alscher et al. 2002). Upon confronted by stresses, plants generally produce increased amounts of SODs which act as a part of the innate immunity of plants and is highly correlated with the resistance in plants (Lightfoot, et al. 2016). These results validate that in resistant NIDW295 and PDW314 cultivars SOD optimizes the ROS whereas in susceptible A-9-301 and Bijaga Yellow cultivars, the low SOD activity, was less effective in detoxifying the ROS hence experienced greater damage.

\section{Catalase}

Amongst the enzymes involved in the scavenging of the surplus $\mathrm{H}_{2} \mathrm{O}_{2}$ produced spontaneously or by $\mathrm{O}^{2}-$ dismutation via SOD, CAT plays a major role. In the present study, Bipolaris sorokiniana infection induced CAT activity in leaves of all the durum wheat cultivars and 1.2-1.6 folds increase was observed in susceptible (A-9-301 and Bijaga Yellow) and resistant (NIDW295 and PDW314) cultivars respectively. Davar et al., (2013) reported a significant 3-fold increase in the CAT activity in resistant sunflower line inoculated with Sclerotiana sclerotiorum. The increase in CAT activity may be related to increased oxidative stress tolerance (Yarden et al. 2014). The balance between SOD, CAT and peroxidase activities is important for determining the intracellular level of $\mathrm{H}_{2} \mathrm{O}_{2}$ and in low concentrations $\mathrm{H}_{2} \mathrm{O}_{2}$ can act as stress signal. The induced CAT activity in the present study seems to induce tolerance towards Bipolaris sorokiniana infection by maintaining $\mathrm{H}_{2} \mathrm{O}_{2}$ homeostasis. 


\section{Glutathione Reductase}

In the present study, alterations in the GR activity in leaves of wheat cultivars after B.sorokiniana infection was analysed. The GR activity in the leaves of the inoculated cultivars of NIDW295 and PDW314 (resistant) was 2.4 folds greater compared to that of control, confirming their high level of resistance to oxidative stress induced by spot blotch. In contrast, the GR activity only increased slightly in the leaves of susceptible (A-9-301 and Bijaga Yellow) cultivars. GR activity in the resistant plants was increased greatly in the resistant plants of apricot after inoculation with the Plum pox virus in comparison with the susceptible (Hernandez et al. 2001). Glutathione reductase recycles glutathione disulfide (GSSG) to GSH and the quick and constant increase in glutathione abundance participates in detoxification of ROS as well as signaling in plant protection against biotic and abiotic stresses (Ghanta and Chattopadhyay, 2015). NIDW295 and PDW314 (resistant) cultivars with higher induced GR activity maintain the balance of the GSH/GSSG cycle and impart the oxidative defence during B.sorokiniana infection.

\section{Nitrate Reductase}

The primary role of NR in plants is NAD (P) H-dependent reduction of nitrate to nitrite, which is subsequently reduced to ammonium by the nitrite reductase. (Lea, 1993). NR plays an essential role during phytopathogenic interactions by supplying substrates for the synthesis of nitric oxide (NO), a key signal for plant defense responses (Salgado et al. 2013). B.sorokiniana infection resulted in reduced nitrate reductase activity in leaves of all durum wheat cultivars. The reduction was more evident in susceptible A-9-301 and Bijaga Yellow cultivars than in resistant NIDW295 and PDW314 cultivars. Similar results were obtained by Sarsenbaev et al. in their analysis on consequences of leaf rust infection on the activity of nitrate reductase (NR) of the spring wheat varieties. The maximum decrease in NR catalytic activity may be due to inactivated form of NR or protease degradation of NR triggered by pathogen infection. This decrease would be sufficient to prevent optimal nitrate assimilation in susceptible cultivars and inhibit NO synthesis involved in defense mechanisms.

\section{Nitrite Reductase}

Nitrite reductase in plants catalyses the reduction of nitrite to ammonium. The ammonium is then incorporated into amino acids and other nitrogen derived compounds through the glutamine synthetase/glutamine-2- oxoglutarate transaminase system (Lea, 1993). In the present study, nitrite reductase was decreased in B. sorokiniana inoculated leaves compared to control leaves and susceptible A-9-301 and Bijaga Yellow cultivars showed maximum decline in NiR activity. Coordination of NR and NiR activities to avoid accumulation of cytotoxic nitrite is very important aspect of regulation of nitrogen metabolism (Gupta and Beevers, 1983). Lower NiR activities in susceptible cultivars may lead to accumulation of nitrite which can be detrimental to the plant.

\section{CONCLUSIONS}

The present study revealed higher activities of antioxidant enzymes SOD, CAT and GR in the defence response of resistant NIDW295 and PDW314 cultivars against Bipolaris sorokiniana infection compared to susceptible A-9-301 and Bijaga Yellow cultivars. Slight decrease in activities of NR and NiR enzymes observed in resistant cultivars indicate the ability of cultivars to efficiently regulate nitrogen metabolism under Bipolaris sorokiniana induced stress. Thus significant differences in antioxidant enzyme and nitrate assimilatory activities were observed between the resistant and susceptible cultivars which may serve as an useful tool in selection of resistant cultivars. However, further profiling of isozymes of the antioxidant enzymes are needed to confirm the genes unique to resistant durum wheat cultivars and thus may provide 
useful markers for spot blotch resistance.

\section{ACKNOWLEDGEMENTS}

We extend our thanks to Directorate of Research, University of Agricultural Sciences, Dharwad, India for the financial support, the fellowship and AICRP on wheat MARS, Dharwad for providing amenities for field experiments. We thank Dr. Ashalatha K V and Dr A R S Bhat for their guidance in statistical analysis.

\section{REFERENCES}

1. Chowdhury, A., Singh, G., Tyagi, B.S., Ojha, A., Dhar, T. and Bhattacharya, P.M. (2013). Spot blotch disease of wheat - a new thrust area for sustaining productivity. Journal of Wheat Research, 5 (2), 1-11.

2. Joshi, L. M.,. Singh, D.V. and Srivastava K.D.(1986): Wheat and wheat diseases in India. In: L. M. Joshi, D. V. Singh, and K. D. Srivastava (eds), Problems and Progress of Wheat Pathology in South Asia, 11-19. Malhotra Publishing House, New Delhi.

3. Duveiller, E., and Gilchrist, L. (1994): Production constraints due to Bipolaris sorokiniana in wheat: current situation and future pros- pects. In: D. A. Saunders, and G. P. Hettel (eds), Wheat in Heat-Stressed Environments: Irrigated, Dry Areas and Rice-Wheat Farming Systems, 343-352. CIMMYT, Mexico, D.F.

4. Kumar, S., Archak, S., Tyagi, R..K., Kumar, J., Vikas, V. K., Jacob. S.R. et al. (2016). Evaluation of 19,460 Wheat Accessions Conserved in the Indian National Genebank to Identify New Sources of Resistance to Rust and Spot Blotch Diseases. PLoS ONE 11(12): e0167702.doi:10.1371/journal.pone.0167702.

5. Acharya, K., Dutta, A.K. and Pradha, P. (2011). Bipolaris sorokiniana (Sacc.) Shoem.: The most destructive wheat fungal pathogen in the warmer areas. Australian Journal of crop Science, 5(9):1064-1071.

6. Bradley, D.J., Kjellbom, P., Lamb, C.J. 1992 Elicitor and wound-induced oxidative cross-linking of a proline-rich plant cell wall protein: a novel, rapid defense response. Cell, 70, 2130.

7. Brisson, L.F., Tenhaken, R., Lamb, C. 1994 Function of oxidative cross-linking of cell wall structural proteins in plant disease resistance. Plant Cell, 6, 17031712.

8. Bowles, D.J. 1990 Defense-related proteins in higher plants. Annu. Rev. Biochem., 59, 873907.

9. Ingram, D. S. (1978). Cell death and resistance to biotrophs. Ann Appl Biol, 89, 291-295.

10. Tenhaken, R., Levine, A., Brisson, L. F., Dixon, R. \& Lamb, C. (1995). Function of the oxidative burst in hypersensitive disease resistance. Proc Natl Acad Sci U S A 92, 4158-4163.

11. Wojtaszek, P. (1997). Oxidative burst: an early plant response to pathogen infection. Biochem J 322, 681-692.

12. Mittler, R. (2002). Oxidative stress, antioxidants and stress tolerance. Trends Plant Sci 7, 405-410.

13. Waller, F., Baltruschat, H., Achatz, B., Becker, K., Fischer, M.. et al. (2005). The endophytic fungus Piriformospora indica reprograms barley to salt-stress tolerance, disease resistance, and higher yield. Proc Natl Acad Sci U S A 102, 13386-13391.

14. Srivastava, H.V. (2002). Regulation of nitrate reductase activity in higher plants. Phytochemistry, 19(5), 725-733.

15. Mali. K., Mirajkar, K. K., Biradar, S., Patil. R.S. (2017). Role of defence related enzymes and lignin in host resistance of durum wheat cultivars infected by Bipolaris sorokiniana

16. Bradford, M. M. (1976). Rapid and sensitive method for the quantitation of microgram quantities of protein utilizing the principle of protein-dye binding. Analytical. Biochemistry, 72, 248-254. 
17. Beauchamp, C., Fridovich, I. (1971). Superoxide dismutase, improved assays and an assay applicable to acrylamide gels. Analytical. Biochemistry, 44, 276-287.

18. Beers, R. F. and Sizer, I. W. (1952). A spectrophotometric method for measuring the breakdown of hydrogen peroxide by catalase. Journal of Biological Chemistry. 195, 133-140.

19. Mavis, R. D. and Stellwagen, E. (1968). Purification and subunit structure of glutathione reductase from Bakers' Yeast. Journal of Biological Chemistry, 243, 809 -814.

20. Hageman, R.H. and A.J. Reed. (1980). Nitrate reductase from higher plants. Methods EnzymoL, 69, 270-280.

21. Wray, J.L. and Fido, J. (1990) Nitrate reductase and nitrite reductase. In: Methods in Plant Biochemistry, Vol. 3, Enzymes of Primary Metabolism (P.J. Lea, ed.) Academic Press, London. pp. 241-256.

22. Beauchamp, C. and Fridovich, I. (1971). Superoxide dismutase, improved assays and an assay applicable to acrylamide gels. Analytical. Biochemistry, 44, 276-287.

23. Beers, R. F. and Sizer, I. W. (1952). A spectrophotometric method for measuring the breakdown of hydrogen peroxide by catalase. Journal of Biological Chemistry. 195, 133-140.

24. M. K. Mahatma, Bhatnagar, R., Mittal, G. K. and Mahatma, L. 2011. Antioxidant metabolism in pearl millet genotypes during compatible and incompatible interaction with downy mildew pathogen.

25. M. P. Babitha, S G. Bhat, H. S. Prakash and H. S. Shetty. (2002). Differential induction of superoxide dismutase in downy mildew-resistant and -susceptible genotypes of pearl millet. Plant Pathology, 51, 480-486.

26. Alscher, R..G., Erturk, N. and Heath, L. S. (2002). Role of superoxide dismutases (SODs) in controlling oxidative stress in plants. J Exp Bot, 53:1331-41; PMID:11997379; DOI:10.1093/jexbot/53.372.1331.

27. Lightfoot, D. J., Graham R. D., Mc Grann, Able1, A.J. (2016). The role of a cytosolic superoxide dismutase in barley-pathogen interactions. Molecular Plant Pathology, DOI: 10.1111/mpp.12399.

28. Davar,R., Darvishzadeh, R., and Majd, A. (2013) Changes in antioxidant systems in sunflower partial resistant and susceptible lines as a $\square$ ected by Sclerotinia sclerotiorum. Biologia, 68(5): 821-829.

29. Yarden, O., Veluchamy, S., Dickman, M.B. and Kabbage, M. 2014. Sclerotinia sclerotiorum catalase SCAT1 affects oxidative stress tolerance, regulates ergosterol levels and controls pathogenic development. Physiological and Molecular Plant Pathology, 85,34-41.

30. Hernández, J.A., Talavera, J. M., Martínez-Gómez, P., Dicenta, F., Sevilla F. (2001). Response of antioxidative enzymes to plum pox virus in two apricot cultivars. Physiol Plant. 111(3):313-321.

31. Ghanta, S. and Chattopadhyay, S. (2011).Glutathione as a signaling molecule. Another challenge to pathogens. Plant. Signal. Behaviour, 6, 783-788.

32. Lea, P. J. (1993). Nitrogen Metabolism. In: Lea PJ, Leegood RC (eds) Plant biochemistry and molecular biology. Wiley, New York, pp 155-180.

33. Salgado, I., Carmen Martínez, M., Oliveira, H.C. et al. Braz. J. Bot (2013) 36: 89. doi:10.1007/s40415-013-0013-6

34. Sarsenbaev,K. N.,.Abiyev, S.A., Kozhamzharova, L.S., Yessimsiitova,Z., Babenko, O. and Zh. Bazarbayeva. (2013). Effect of Leaf Rust on the Molybdenum-Containing Enzymes Activity in Spring Wheat Varieties Differing in Resistance to Infection. World Applied Sciences Journal 25 (9): 1308-1313, 2013 ISSN 1818-4952 (C) IDOSI Publications, DOI: 10.5829/idosi.wasj.2013.25.09.13426. 
Durum Wheat Cultivars' Antioxidant and Nitrate Assimilatory

Enzyme Response to Bipolaris Sorokiniana Infection

35. Gupta, S.C. and Beevers, L. 1983.Environmental influences on Nitrite reductase activity in Pisum sativum L. seedlings. J Exp Bot. (1983) 34 (11): 1455-1462. DOI: https://doi.org/10.1093/jxb/34.11.1455. 
